\title{
Upper Intestinal Mucosal Proliferation in the Newborn Guinea Pig: Effect of Composition of Milk Feeds
}

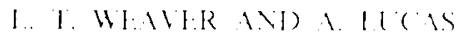

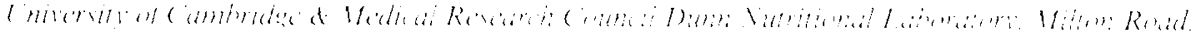 \\ (imbridest linelund
}

\begin{abstract}
ABSIRACT. To examine the effects of first enteral feeds on the development of the gastrointestinal tract. the changes in upper intestinal mucosal morphology and $\mathrm{ki}-$ netics were studied during the $1 \mathrm{st}$ wh of postnatal life in neonatal guinea pigs. Animals were reared either on mother's milk or on a cow's milk formula isocaloric with guinea pig milk. Mucosal crypt-villus architecture was measured by microdissection, and mucosal kinetics were measured using a metaphase arrest technique. (omparable growth was achieved between the two feeding groups. There were no significant differences in the villus heights, crypt depths. or erypt:villus ratios between the naturally fed and formulafed guinea pigs. The formula fed had a crypt cell production rate twice as high as the naturally fed animals throughout the study period $(p)<0 .(0) 1)$. The higher mucosal proliferation rate of the formula-fed animals may be due to the absence of growth-modulating factors in this milk. or a regenerative response to "damage" of the upper intestinal mucosal by cow s milk proteins. (Pediatr Re's 22: 675 678. 1987)
\end{abstract}

Abbreviations

C Mr. cow's milk formula

(cPR, crypt cell production rate

Clit, epidermal growth factor

We have previously described marked ditterences in the pascive intestinal permeabilits of heast and ( $\mathrm{Mll}$-fed human neonates and newborn guinca pige (1). The ( 111 - fied guineal pige showed a persistently hister intestinal permeability to lactulose than the breast-fed guineal pigs throughoun the ist wh of life. Ihese changes were nol atsocialled with differences in unper intersinal mecosal histotoge between the two feeding groups.

Such diflerences in passive intestinal permeatilits in response to composition of enteral feeds mats be due te differences in rate of mucosal turnoser altrastructural morphologs. or enterocrte differentiation and function (2).

In the ahsence of differences in mucosil morpholeges in the

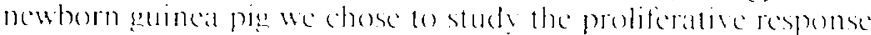
of the upper incestinal cpithelium to milk fecting to dekermine whether the mathed differences in intestinal permeathilits of the naturally and ( $M 11-f i d$ animals were associated with differences

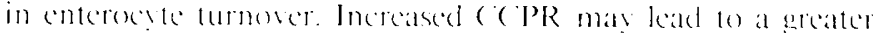

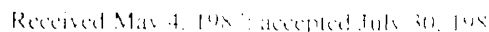

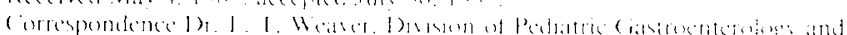

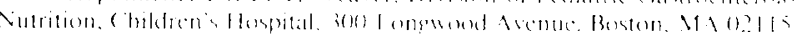

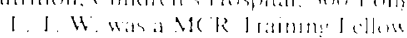

villus population of immature onteresy kes forming: an eppithelium with altered permeabilits rharateristics.

We used a metaphase arrese technigue to measure upper intestinal mucosal proliteration during the lat wh of postmatal life. As in our cartice sudy we chese the guineal pig as a model with which to investigate the differences in passise intestinal permeability seen hetween hreast-and ( Mef-ficd heman infants (1). hecause. like man. it aceunes the majorits of its circulatine? antibeds tansplacentally and undergoes intestimal ckesure soon after birth (3) Voreoser it is comparallised malluse and independent at hirth and mal be separated trom its mother and reared independently on an artificial milk formulat.

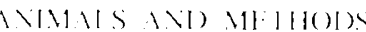

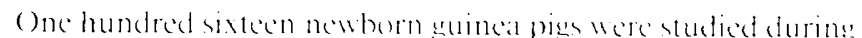

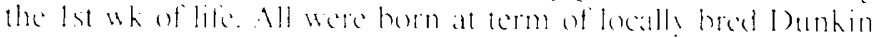

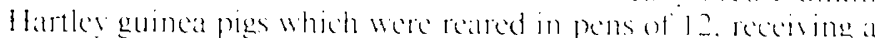

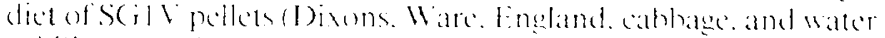
wet lihitum. After hirth naturatly fid lithers were abed with their

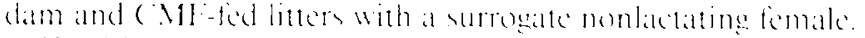

Vertrition. Vewborn guinea piges were divided into awo lieding geroups. Sixty-fice naturaliy fed anmals remained with the ir dam from birth and were allowed to suckle ad lihinmm. In commonn with their mothers they were allowed alceses lo solid pellets

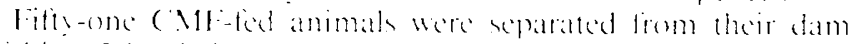
within 15 h of hirth and fed with a com i mith-hased formula

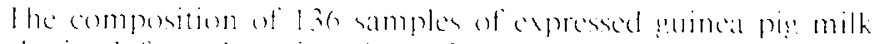
obtained from latetating dams 2 10 15 dass postpartum was analyed. I fermulat composed of pasteuried cow s mith and

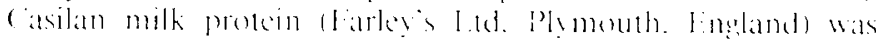
designed to mimic the composition of natural endincet pie milk

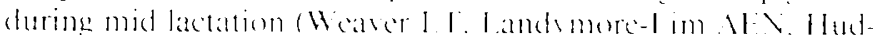

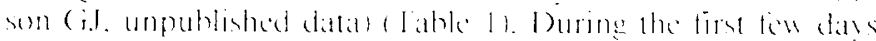

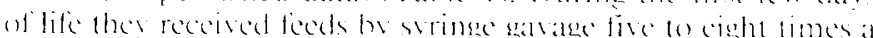

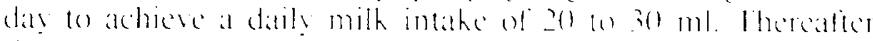

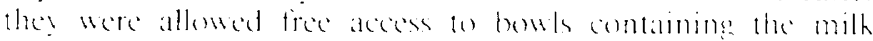
termula as well an solid pellets

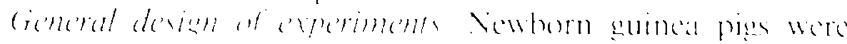
reared as abose untel the were killed at intersals up we postmatal life. Daly of hioh was called da! 1 . On the das of the

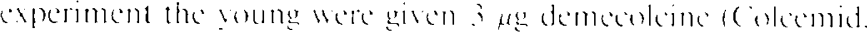

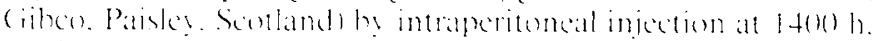
Preliminary studies showed that this dese alrested miteses at metaphase without anaphase exape or degencration. and with lincarits of metaphase aceumulation (5). Anmals were hilled at Bl-min intervals thereatter he corical dislexation. I he ahdomen was opened hy longitudimal midline incision and the sut was

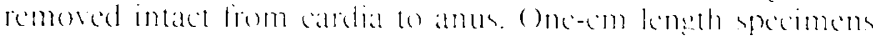

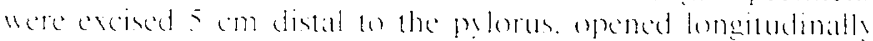


and laid, mucosal side up, on a card before preservation in Clarke's fixative ( $75 \%$ ethanol, $25 \%$ acetic acid).

Microdissection. After fixation in Clarke's solution for 24-h specimens were preserved in $75 \%$ ethanol until staining with Schiff reagent by the Feulgen reaction (5). This was preceded by rehydration through descending concentrations of ethanol and hydrolysis with $\mathrm{M} \mathrm{HCl}$ at $60^{\circ} \mathrm{C}$ for $6 \mathrm{~min}$. Individual crypt-villus units were dissected under a stereomicroscope at $\times 20$ magnification, suspended on a slide under a cover slip in $45 \%$ acetic acid, and the following measurements were made.

Crypt-Villus Architecture. The heights of 10 well-orientated villi and the depths of 10 mature crypts per animal were measured under $\times 40$ and $\times 250$ magnification respectively using a 1 $\mathrm{mm}$ graduated evepiece graticule. The ratio of the number of crypts to each villus was measured as described by Wright and Irwin (6).

Crypt Cell Production Rate. Gentle pressure was applied to the cover slip to produce squash separation of individual crypts. The number of well stained arrested metaphase figures per 10 complete undamaged crypts was measured. A litter of at least three animals was used per measurement. The CCPR was calculated from the slope of the plot of the mean number of metaphase arrests per crypt per animal against time after administration of demecolcine $(6,7)$. Only results in which a correlation coefficient of $>0.8$ was obtained were used.

Table 1. Composition of natural guinea pig milk and CMF

\begin{tabular}{|c|c|c|}
\hline Composition & $\begin{array}{l}\text { Expressed guinea } \\
\text { pig milk }\end{array}$ & $\begin{array}{l}\text { Artificial } \\
\text { formula* }\end{array}$ \\
\hline Protcin $(\mathrm{g} / 100 \mathrm{ml})$ & $8.1^{-1}$ & 8.1 \\
\hline Fat $(\mathrm{g} / 100 \mathrm{ml})$ & 4.0 & 3.8 \\
\hline $\begin{array}{l}\text { Carbohydrate (lactose) (g/ } \\
100 \mathrm{ml})\end{array}$ & 4.3 & 4.6 \\
\hline Sodium (mmol/liter) & 18 & 17 \\
\hline Potassium (mmol/liter) & 39 & 23 \\
\hline Energy $(\mathrm{kcal} / 100 \mathrm{ml})$ & 85 & 84 \\
\hline Osmolality (mosmol $/ \mathrm{kg}$ ) & 285 & 288 \\
\hline
\end{tabular}

Table 2. Body wt (g) of naturally and CMF-fed guinea pigs during first 8 postnatal days of life

\begin{tabular}{|c|c|c|c|c|c|c|}
\hline \multirow[b]{2}{*}{ Day } & \multicolumn{3}{|c|}{ Naturally fed } & \multicolumn{2}{|r|}{ CMF-fed } & \multirow[b]{2}{*}{ SD } \\
\hline & $n$ & Mean & $\mathrm{SD}$ & $n$ & Mean & \\
\hline 1 & 2 & 92 & 4 & 3 & 95 & 5 \\
\hline 2 & 7 & 91 & 22 & 4 & 104 & 3 \\
\hline 3 & 11 & 92 & 17 & 2 & 95 & 7 \\
\hline 4 & 12 & 97 & 16 & 13 & 94 & 18 \\
\hline 5 & 11 & 101 & 14 & 14 & 100 & 19 \\
\hline 6 & 14 & 95 & 20 & 4 & 82 & 11 \\
\hline 7 & 4 & 108 & 17 & 7 & 105 & 15 \\
\hline 8 & 4 & 116 & 18 & 4 & 118 & 7 \\
\hline
\end{tabular}

Statistics. The results of measurements of crypt-villus architecture were expressed as mean villus heights, crypt depths, and crypt:villus ratios of animals of each age and feeding group calculated from 10 measurements per animal. The unpaired Student's $t$ test was used to test the significance of differences in mucosal achitecture between the two feeding groups.

The significance of the differences between feeding groups in mucosal proliferation rates with time was tested by deriving equations to describe the relation between CCPR and postnatal age, and then determining whether there were significant differences between the slopes and intercepts.

\section{RESULTS}

Growth. Comparable growth was achieved between the two feeding groups (Table 2). The number of animals studied on each day is shown. All animals thrived and none showed any adverse effects of CMF feeds.

Crypt:villus architecture. There were no significant differences in the villus heights, crypt depths, or crypt:villus ratios between the naturally and CMF-fed animals and there were no changes with increasing postnatal age (Table 3).

Crypt cell production rates. Ten naturally fed and $12 \mathrm{CMF}$-fed litters were studied. Figure 1 shows the CCPRs of the naturally and CMF-fed animals plotted against postnatal age.

The slope of the regression line for the naturally fed guinea pigs was 0.11 and that for the CMF-fed animals 0.16 . There was no significant difference between these two slopes. However, there was a significant difference between the intercepts $(p<$ 0.001 ): that of the naturally fed was 1.9 and that of the CMF-fed was 3.7. These results indicate that the CMF-fed animals had a CCPR almost twice that of the naturally fed throughout the study

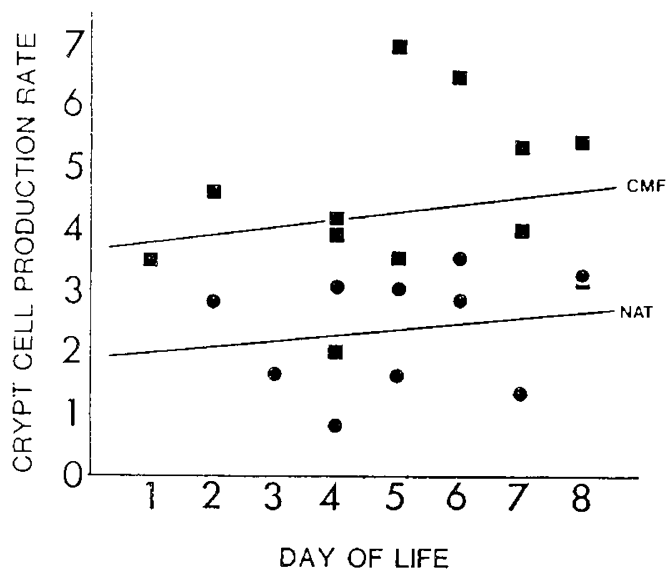

Fig. 1. Crypt cell production rates (arrested metaphases/crypt/h) of naturally fed ( Nat ) and CMF-fed (অ) guinea pigs during the 1st wk of postnatal life. The difference between the intercepts was significant at $p$ $<0.001$.

Table 3. Villus and crypt morphometry (mean and SD) of naturally and CMF-fed guinea pigs during first 8 days of postnatal life**

\begin{tabular}{|c|c|c|c|c|c|c|c|c|}
\hline \multirow[b]{2}{*}{ Day } & \multirow[b]{2}{*}{$n$} & \multicolumn{2}{|c|}{ Naturally fed } & \multirow[b]{2}{*}{$C: V$} & \multicolumn{4}{|c|}{ CMF fed } \\
\hline & & $\mathrm{VH}(\mu \mathrm{m})$ & $C D(\mu \mathrm{m})$ & & $n$ & $\mathrm{VH}(\mu \mathrm{m})$ & $\mathrm{CD}(\mu \mathrm{m})$ & $\mathrm{C}: \mathrm{V}$ \\
\hline 1 & 2 & $1014(90)$ & $160(8)$ & $6.0(0.3)$ & 3 & $981(29)$ & $163(7)$ & $5.6(1.2)$ \\
\hline 2 & 7 & $1021(118)$ & $131(8)$ & $5.2(0.7)$ & 4 & $1114(111)$ & $174(12)$ & $7.1(0.6)$ \\
\hline 3 & 11 & $962(154)$ & $154(20)$ & $5.1(0.6)$ & 2 & $1121(95)$ & $139(10)$ & $5.3(0.4)$ \\
\hline 4 & 12 & $1069(169)$ & $169(24)$ & $4.9(1.0)$ & 13 & $815(178)$ & $140(20)$ & $4.6(0.4)$ \\
\hline 5 & 11 & $985(145)$ & $155(29)$ & $5.0(0.8)$ & 14 & $1057(112)$ & $163(28)$ & $4.6(0.7)$ \\
\hline 6 & 14 & $911(166)$ & $166(21)$ & $5.6(0.7)$ & 4 & $976(83)$ & $179(18)$ & $5.7(0.5)$ \\
\hline 7 & 4 & $985(100)$ & $193(21)$ & $5.4(0.2)$ & 7 & $841(232)$ & $170(31)$ & $4.6(0.6)$ \\
\hline 8 & 4 & $934(63)$ & $206(13)$ & $6.0(0.4)$ & 4 & $841(122)$ & $157(63)$ & $4.4(0.1)$ \\
\hline
\end{tabular}

* $\mathrm{VH}$, villus height; $\mathrm{CD}$, crypt depth; $\mathrm{C}: \mathrm{V}$, crypt:villus ratio. 
period. The ( during the lirst 8 days ol postnatal lifi

\section{J)TS(ISTSO)}

Cur study shems signilicant dilferences in the upper intestinal mucosal prolitiallive response of newborn guinea pigs 10 composition of enteral feeds. from the indiation ol enteral feeding throughout the Ist postmatal wh the ( Mr-led amimats showed a persistently hisher ( $(\mathrm{PR}$ than the naturally fod animals. There was a gradual rise in ( ( PPR with increasing age in hoth fecting groups. lising microdissection for the measurement of eryptvillus architecture we have showed no morphological diflerences between the two fecoling groups. nof amy histological changes with increasing postmatal age.

Adaptation of the intestinal mucosa to the intiation of enteral nutrition mav be measured as changes in crvpt-villus architecture and epithelial cell turnowes. The metaphase arrest ecthnigue allows a direce measume of the rate of entre ol now colls inte mitosis. and in a wide range of eonditions it has heon shown 10 agrec closely with fritiated themidins labeling technigues (7). Using the microdissection technigues described hoth villus herght and erypl depth, and the number of cropts serving and villus (c $: V$ ration) were measured. The ate of mew edl production pen crypt (c ( P R measured by metaphase arrest) mulliplice by the cryptivillus ratio is a measure of the net villus influx. In the absence of diflerences in villus height. crypt clephls. and ( I ratio between the two feeding groups. or wh increasing postnatal age. the elevaled ( ( P R ol the ( MH - fed animals represents a mue increase in mocosal turnover rate in respernse to this milk lormula.

Maturation of the sastorintestimal mucosa ocents under the influence of both intratuminal and extraluminal factors (s). Among the fomere composition of milk feceds mat be the most importatut.

The milk of mammats contains a range of trophic fitcous. hormones, and other hiologicalls active substances (9) which mat exed growth-motulatingeffects on the gastrointestinal mucosal (10). Their concentrations ate highest in colostrum (b) and it has beren observed that spithelial cell lines gnow more readils in colostrum than in okler milk (11). Recently the presenes of

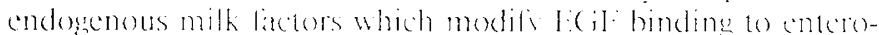

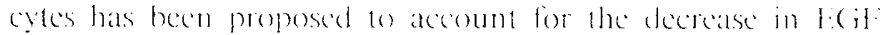
hinding alter birth (12). It is therelote possible that our lindings of a greater ('PR in the formubled amimals were due 10 an absence of modulating laters in the artiticial milk. or wen the presence of inhibitors in natural milk. which moditied the eontrol of mucosal prolifiration.

An allernative explanation is that ( Ml caused an cherated c ('PR as a regencratice response 60 "damatse" of the small intestinal mucosa hy cow"s milk pootcins. Such damage is suggested by the devated passive indestinal permebility describer in our carlier stadv (1) and mal he mediated by binding of cows milk profeins a an immature (p)ithelial surface with distuption of mucosill incerill

Support for this hypothesis has beco presented in a mextel ot

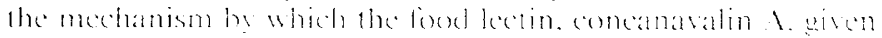
by mouth a neomalal guinea prgs. induced a brisk increase in ("PR in association with an clevated passive intestinal permeability o laceulose (1.3). Binding of concanavalin A to inclividual microvillat componculs and acessibitits of the lectio we noth

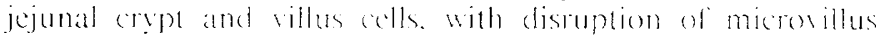
architecture, were also shown. (domonstrating how an ingerted profein mal anse such changes as chescribed herein.

Futher suppon low this hypothesis comes from studies at the neomatal rat. Sero e al (1.1) hase shown bat hoth hindine and uptake of mith ponteins by the intestinal mucosa is greater in

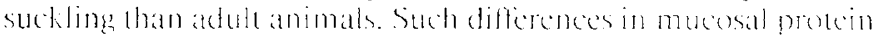
handling are associated with diflerences in microvillous membranc compositon betwen immature and mature andmals! 1 i.

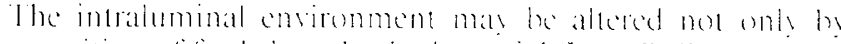

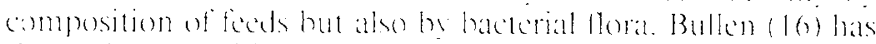

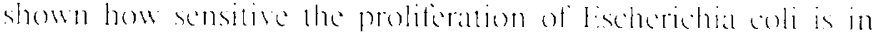

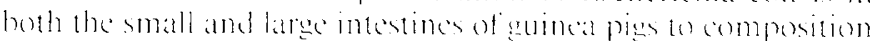

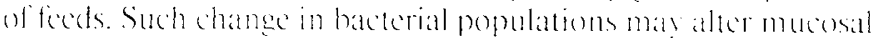

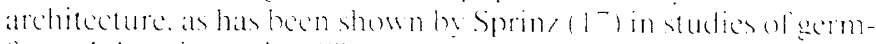

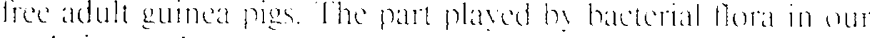
study is not shown.

lixtraluminal factors maty atso be insolved in the lindings we hate described. The effects of matemal depris atom were minimised by ratring the ( Ml - fed amimats with a surgenate mother

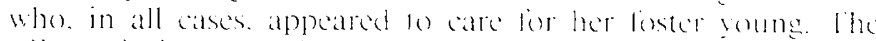
effect of diumal vathation on (CPR (ls) was climinated h performing all studics at the same time of dal

It is possibk that the findings described itere mediated on regulatery peptides ateting locally or wa intermediale pallowas

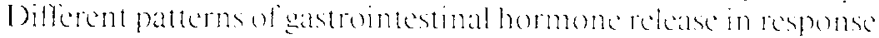

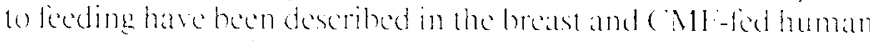

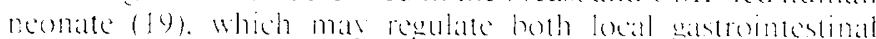
responses and more distant metabolic responses bo enteral nutri(i) $)$.

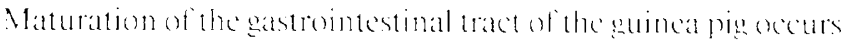
late in gestation. hut hy full term (0, dass) linger-shaped intes-

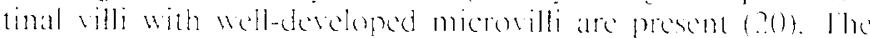

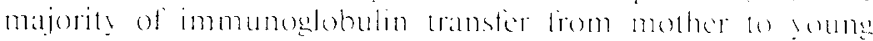

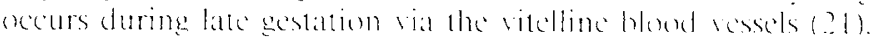

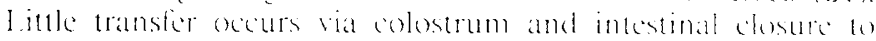

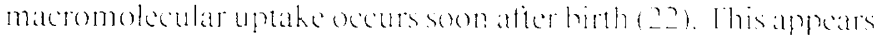

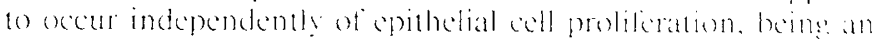

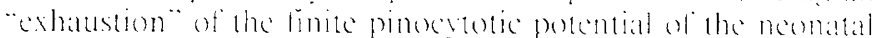
enterocyte membrame (23). In increase in the lengh and number

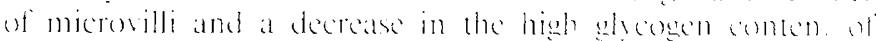
comerocyes (24) hilloms.

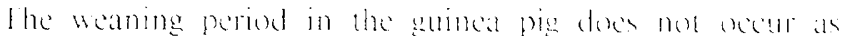
abruptly as that of the rat and mouse. It is assoctated with a gradual transition in mucosal function fiom ons concended wh the digestion and absopption of mith lo solid fored (25). In the rat and mousc weaning is not onls associatce with incertimal chosure and abrupt changes in the mucesal hydrolase protikes (23. 26). but also wilh an increase in villus hedehts and ely pell

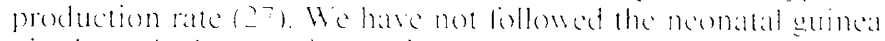

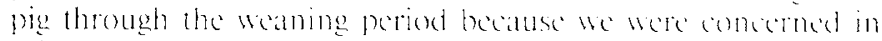
this study with the impale of intiation of mith lecelins? on gastrointestinal mucosal structure and lindetion.

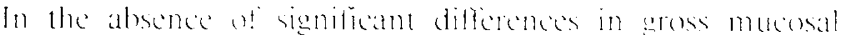

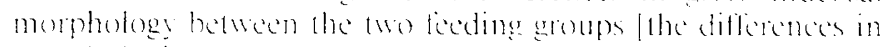
morphologial masurements bescribed hecon and anlise (1) were due to differences in techmiques of tissue fixalton and preparation involed in the micredissedion and standart histo-

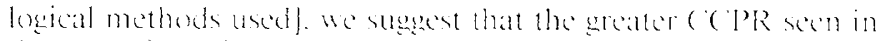

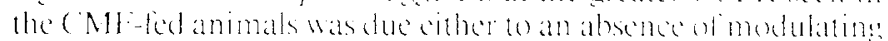

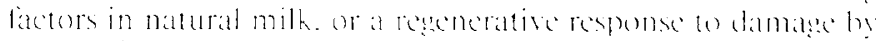

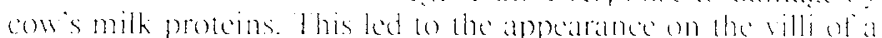

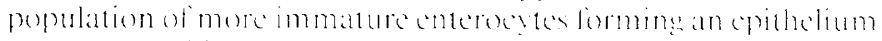
more permeable to small water-soluble mathers. perhape through

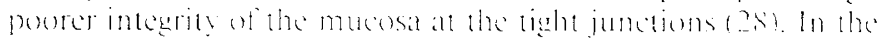

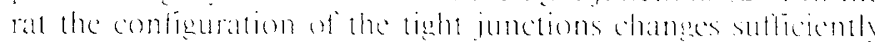

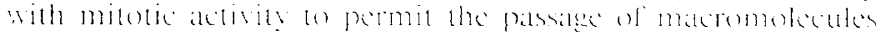

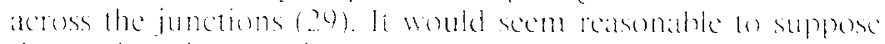

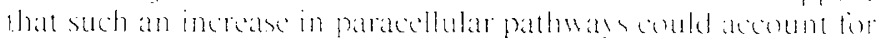

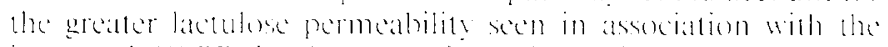

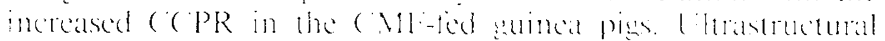
studies of the mucesie with special attention on the tisht fume-

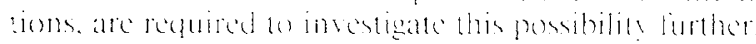

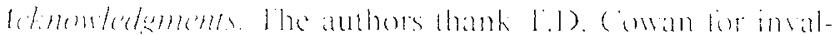

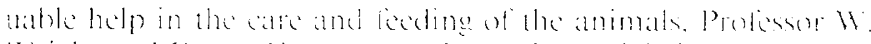

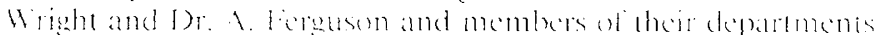

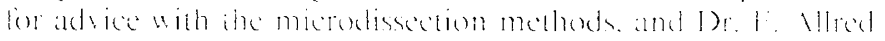
for help with the satistical analesis. 


\section{REFERENCES}

1. Weaver LT, Laker MF, Nelson R, Lucas A 1987 Milk feeding and changes in intestinal permeability and morphology in the newborn. J Pediatr Gastroenterol Nutr 6:351-358

2. Van Dongen JM, Visser WJ, Daems W Th. Galjaard H 1976 The relation between cell proliferation, differentiation, and ultrastructural development in rat intestinal epithclium. Cell Tissue Res 174:183-199

3. Weaver LT, Koritz TN, Coombs RRA 1987 Tolerance to orally induced anaphylactic sensitisation to cow's milk proteins and the patency of the intestinal mucosa in the neonatal guinea pig. Int Arch Allergy Appl Immunol $83: 220-222$

4. Deleted in proof.

5. Tannock IF 1965 A comparison of the relative efficiencies of various mataphase arrest agents. Exp Cell Res 47:345-356

6. Wright NA, Irwin M 1982 The kinetics of villus cell populations in the mouse small intestine. I. Normal villi: the steady state requirement. Cell Tissue Kinet 15:595-609

7. Wright NA, Appleton DR 1980 The metaphase arrest technique. A critical review. Cell Tissue Kinet 13:643-663

8. Lebenthal E, Lee PC 1983 Interactions of determinants in the ontogeny of the gastrointestinal tract: a unified concept. Pediatr Res 17:19-24

9. Koldovsky O, Thornburg W 1987 Hormones in milk. J Pediatr Gastroenterol Nutr 6:172-196

10. Read LC, Upton FM, Francis GL, Wallace JC, Dahlenberg GW, Ballard FJ 1984 Changes in the growth-promoting activity of human milk during lactation. Pediatr Res 18:133-138

11. Steimer KS, Packard R, Holden D, Klagsbrun M 1981 The serum-free growth of cultured cells in bovine colostrum and in milk obtained later in the lactation period. J Cell Biol 109.223-224

12. Toyoda S, Lec PC. Lebenthal E 1986 Interaction of epidermal growth factor with specific binding sites of enterocytes isolated from rat small intestine during development. Biochim Biophys Acta 889:295-301

13. Weaver LT, Bailey DS 1987 Effect of the lectin concanavalin A on the neonatal guinea pig gastrointestinal mucosa in vivo. J Pediatr Gastroenterol Nutr $6: 445-453$

14. Stern M, Pang KY, Walker WA 1984 Food proteins and gut mucosal barrier II Differential interaction of cow's milk proteins with the mucous coat and surface membrane of adult and immature rat jcjunum. Pediatr Res 18:1252 1257

15. Pang KY, Bresson JL, Walker WA 1983 Development of the gastrointestinal mucosal barrier. IV. Evidence for structural differences in microvillous membranes from newborn and adult rabbits. Biochim Biophys Acta 727:201-208

16. Bullen JJ 1976 Iron-binding proteins and other factors in milk responsible for resistance to Escherichia coli. In: Elliott $\mathrm{K}$ (ed) Acute Diarrhoea in Childhood. Excerpta Medica, Amsterdam, pp 149-169

[7. Sprinz H 1962 Morphological response of the intestinal mucosa to enteric bacteria and its implication for sprue and Asiatic cholera. Fed Proc 21:5764

18. Al-Nafussi AI, Wright NA 1982 Circadian rhythm in the rate of cellular proliferation and in the size of the functional compartment of mouse jejunal epithelium. Virchows Arch 40:71-79

19. Lucas A, Blackburn AM, Aynsley-Green A, Sarson DL, Adrian TE, Bloom SR 1980 Breast vs Bottle: endocrine responses are different with formula feeding. Lancet 1:1267-1269

20. Bailey DS, Cook A, McAllister G, Moss M, Mian N 1984 Structural and biochemical differentiation of the mammalian small intestine during foetal development. J Cell Sci 72:195-212

21. Barnes JM 1959 Antitoxin transfer from mother to foetus in the guinea-pig. J Pathol Bacteriol 77:371-380

22. Lecce JG, Broughton CW 1973 Cessation of uptake of macromolecules by neonatal guinea pig, hamster and rabbit intestinal epithelium (closure) and transport into blood. J Nutr 103:744-750

23. Rundell JO, Lecce JG 1972 Independence of epithelial cell turnover from cessation of absorption of macromolecules (closure) in the neonatal mouse, rabbit, hamster and guinea pig. Biol Neonate 19:304-326

24. Merrill TG, Sprinz H. Tousimis AJ 1967 Changes in intestinal absorptive cells during maturation: an electron microscopic study of prenatal, postnatal, and adult guinea pig ileum. J Ultrastruct Res 19:304-326

25. Koldovsky O, Heringova A, Jirsova V, Chytil F, Hoskova J 1966 Postnatal changes in beta-galactosidase activity in the jejunum and ileum of mice, rabbits, and guinea pigs. Can J Biochem 44:523-527

26. Henning SJ 1981 Postnatal development: coordination of feeding, digestion and metabolism. Am J Physiol 241:199-214

27. Al-Nafussi, Wright NA 1982 Cell kinetics in the mouse small intestine during immediate postnatal life. Virchows Arch 40:51-62

28. Mora-Galindo J 1986 Maturation of tight junctions in guinea-pig cecal epithelium. Cell Tissue Res 242:169-175

29. Tice LW, Carter RL, Cahil MB 1979 Changes in tight junctions of rat intestina crypt cells associated with changes in their mitotic activity. Tissue Cell 11:293-316 